\title{
Tengsl D-vítamíns og áhættupátta hjarta- og æðasjúkdóma meðal íslenskra barna
}

\author{
Pórunn Hannesdóttir læknir, ${ }^{1,2}$, Hannes Hrafnkelsson læknir ${ }^{1,3}$, Erlingur Jóhannsson lífeðlisfræðingur ${ }^{4,5}$, \\ Emil L. Sigurðsson læknir ${ }^{1,2}$
}

A G R I P

Tilgangur: Að kanna tengsl á milli D-vítamíngilda í blóđi og pekktra áhættupátta fyrir hjarta- og æðasjúkdómum meðal heilbrigðra íslenskra barna og jafnframt að kanna pessi tengsl óháđ líkamspyngdarstuðli (BMI). Efniviður/aðferðir: Metin voru tengsl milli styrks 25-hydroxyvítamín D í blóđi, líkamspyngdarstuðuls og sjö áhættupátta hjarta- og æđasjúkdóma (háprýstings, heildarkólesteróls, HDL, LDL, príglýceríðs, blóðsykurs og styrks insulíns í blóði). Pátttakendur voru 7 ára skólabörn í 6 grunnskólum Reykjavíkur, haustið 2006.

Niðurstöður: D-vítamín var mælt hjá 159 börnum. 35 peirra (22\%) voru undir 37,5 nmól/L, 70 (44\%) á milli 37,5 og 50,0 nmól/L og 55 (34\%) yfir $50 \mathrm{nmó} / / \mathrm{L}$. D vítamínskortur var skilgreindur sem gildi undir $37,5 \mathrm{nmó} / \mathrm{L}$. Ekki reyndist vera marktækur munur á milli kynja, stelpur ( $n: 85=44,2$ nmól/L), strákar (n:74 = 46,9 nmól/L), p-gildi 0,52 milli hópa. Börn með D-vítamínskort höfðu tilhneigingu til að hafa hærri líkamspyngdarstuðul $(p=0,052)$, lægra HDL $(p=0,044)$ og hærra HbA1C $(p=0,015)$ og serum insúlín $(p=0,014)$ samanborið við börn með eðlileg $D$-vítamíngildi, pað er yfir $50 \mathrm{nmó} / \mathrm{L}$. Marktæk fylgni var á milli lágs $\mathrm{D}$-vítamíns og hárra gilda insúlíns i blóði $(p=0,014)$ og hárra gilda HbA1c $(p=0,015)$, óhád líkamspyngdarstuðli.

Ályktanir: D-vítamínskortur hefur verið tengdur við próun hjarta-og æðasjúkdóma. Mikilvægt er að kanna tengsl milli pekktra áhættupátta hjarta- og æðasjúkdóma og D-vítamíns, sérstaklega hjá börnum og ungu fólki. Hugsanlegt er að D-vítamínskortur auki áhættuna á að próa með sér hjartasjúkdóm snemma i lífinu gegnum insúlínviðnám og breytta blóðsykurstjórnun. Mikilvægt er að fylgja opinberum ráðleggingum varðandi D-vítamíngjöf fyrir alla aldurshópa, en rannsóknin sýndi að 2/3 barnanna voru undir peim kjörgildum sem Embætti landlæknis mælir með.

\section{Inngangur}

Mikilvægi D-vítamíns fyrir próun heilbrigðra beina og eðlilegra kalkgilda hefur verið pekkt í langan tíma en á síðustu árum hefur komið í ljós að D-vítamín gegnir einnig mikilvægu hlutverki í ýmsum öðrum líffærakerfum. Pannig virðist D-vítamín stjórna seytingu kalkvakahormóns, ${ }^{1}$ hafa áhrif á renín-angíótensínaldosterón kerfið ${ }^{2}$ og ennfremur hefur D-vítamín bein áhrif á hjartavöðva og æðapel. ${ }^{3}$ Skortur á D-vítamíni hefur verið tengdur við háprýsting, hjartadrep, heilablóðfall og aðra hjarta- og æðasjúkdóma, svo sem sykursýki, hjartabilun og æðakölkun. ${ }^{4}$

Pversniðsrannsóknir hafa sýnt fram á að lágt gildi D-vítamíns í blóði er tengt auknum líkum á áföllum vegna hjarta- og æðasjúkdóma. 5, 6 Ekki er nákvæmlega vitað á hvern hátt D-vítamín hefur pessi áhrif. Nýlegar rannsóknir benda til pess að D-vítamínskortur geti verið sjálfstæður áhættupáttur fyrir hjarta- og æðasjúkdóma. Pannig hafa Giovannucci og félagar fundið út að fullorðnir karlmenn sem eru með lægra gildi 25-hýdroxývítamín D en 37,5 nmól/L voru 2,4 sinnum líklegri til að fá hjartadrep en peir

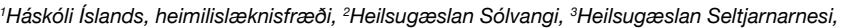
${ }^{4}$ íbrótta- og heilsufræði við Háskóla Íslands, Reykjaviḱ. ${ }^{5}$ Department of Sport and Physical Activity, Bergen University College,Bergen, Norway

Fyrirspurnum svarar Emil L. Sigurdsson emilsig@hi.is

https://doi.org/10.17992//bl.2017.09.149 sem voru með nægilegt D-vítamíngildi (>75 nmól/L). ${ }^{7}$ Rannsóknir á unglingum hafa sýnt fram á öfugt samband 25(OH) D við blóðsykur og príglýseríð en beint samband við gildi HDL-C. ${ }^{8}$

Önnur rannsókn hefur sýnt að D-vítamínskortur var tengdur við aukið insúlínviðnám, minnkaða insúlínframleiðslu og við efnaskiptavillu. ${ }^{9}$ Háprýstingur hefur einnig verið beint tengdur við D-vítamínskort. Pýsk rannsókn hefur m.a. leitt í ljós að einstaklingar með háprýsting sem fengu meðferð með útfjólubláu ljósi prisvar sinnum í viku í prjá mánuði hækkuðu 180\% í serum D-vítamíni og blóðprýstingurinn lækkaði. ${ }^{10}$

Pað er öfugt samband á milli 25(OH)D og kalkvakahormóns, Dvítamínskortur leiðir til ofstarfsemi kalkvaka (hyperparathyroidism) með hærra gildi kalkvakahormóns. Afleiðingar pessa geta á að minnsta kosti prennan hátt leitt til aukinnar áhættu á hjarta- og æðasjúkdómum: Í fyrsta lagi með auknu insúlínviðnámi og truflun á starfsemi beta-frumna í briskirtli sem leiðir til efnaskiptavillu og sykursýki. Í öðru lagi með pví að virkja renín-angíótensín-kerfið og á pann hátt valda hækkuðum blóðprýstingi sem aftur leiðir til pykknunar á hjartavöðva. Í priðja lagi með örvun á bólgum bæði almennt en ekki síst í æðum. ${ }^{11-13}$

Aðalmarkmið pessarar rannsóknar var að kanna tengsl á milli 25(OH)D og pessara pekktu áhættupátta fyrir hjarta-og æðasjúkdómum (HDL, LDL, kólesteróls, blóðprýstings, blóðsykurs, HbA1c og serum insúlíns) meðal heilbrigðra barna og jafnframt að kanna pessi tengsl óháð líkamspyngdarstuðli. 
Tafla I. Meðalgildi áhættupátta hjarta- og æðasjúkdóma miðað við D-vítamíngildi

\begin{tabular}{|c|c|c|c|c|c|c|}
\hline \multirow[t]{2}{*}{ Breytur } & \multicolumn{2}{|c|}{ D-vítamín $<37,5$} & \multicolumn{2}{|c|}{ D-vítamín $>37,5$ og $<50$} & \multicolumn{2}{|c|}{ D vítamín >50 } \\
\hline & $N(\%)$ & $\begin{array}{c}\text { Međalgildi } \\
\text { (staðalfrávik) }\end{array}$ & $N(\%)$ & $\begin{array}{c}\text { Međalgildi } \\
\text { (stađalfrávik) }\end{array}$ & $N(\%)$ & $\begin{array}{c}\text { Meðalgildi } \\
\text { (staðalfrávik) }\end{array}$ \\
\hline Líkamspyngdarstuðull (kg/m²) & $35(22)$ & $16,7(2,3)$ & $70(44)$ & $16.3(2.0)$ & $54(34)$ & $16.0(1.5)$ \\
\hline Systólískur BP (mmHg) & $34(21)$ & $94(7)$ & $70(44)$ & $95(7)$ & $49(31)$ & $94(6)$ \\
\hline Díastólískur BP (mmHg) & $34(21)$ & $55(5)$ & $70(44)$ & $57(5)$ & $49(31)$ & $56(5)$ \\
\hline Kólesteról (mmól/L) & $35(22)$ & $4,3(0,5)$ & $67(42)$ & $4,3(0,8)$ & $54(34)$ & $4,5(0,6)$ \\
\hline HDL (mmól/L) & $35(22)$ & $1,5(0,2)$ & $69(43)$ & $1,5(0,3)$ & $54(34)$ & $1,6(0,3)$ \\
\hline LDL (mmól/L) & $23(27)$ & $2,5(0,4)$ & $33(38)$ & $2,5(0,6)$ & $30(35)$ & $2,6(0,6)$ \\
\hline Príglýseríð (mmól/L) & $35(22)$ & $0,7(0,3)$ & $67(42)$ & $0,6(0,2)$ & $54(34)$ & $0,6(0,2)$ \\
\hline Insúlín (mmól/L) & $35(22)$ & $4,7(2,1)$ & $67(42)$ & $4,2(2,4)$ & $54(34)$ & $3,4(2,2)$ \\
\hline Blóðsykur (mmól/L) & $32(20)$ & $4,6(0,3)$ & $62(39)$ & $4,6(0,2)$ & $52(33)$ & $4,6(0,4)$ \\
\hline HbA1C (mmól/L) & $35(22)$ & $5,5(0,2)$ & $68(43)$ & $5,4(0,3)$ & $54(34)$ & $5,3(0,3)$ \\
\hline
\end{tabular}

\section{Aðferðir og efniviður:}

\section{Dátttakendur}

Pessi rannsókn er hluti af stærri pversniðsrannsókn og hafa niðurstöður úr peirri rannsóknar verið birtar áður. ${ }^{14}$ Tengsl milli styrks 25-hydroxyvítamín D í blóði, líkamspyngdarstuðuls og sjö áhættupátta hjarta- og æðasjúkdóma var metinn (háprýstingur, heildarkólesteról, HDL, LDL, príglýceríð, blóðsykur og styrkur insúlíns í blóði).

Rannsóknarpýðið voru grunnskólabörn úr sex grunnskólum í Reykjavík, sem voru valdir af handahófi. Öllum börnum í öðrum bekk í pessum skólum (fædd árið 1999) var boðin pátttaka. Fengið var upplýst skriflegt sampykki bæði frá pátttakendum og foreldrum. Allar mælingar voru gerðar frá september til nóvember árið 2006. Rannsóknin var sampykkt af Vísindasiðanefnd og Persónuvernd (VSN b200605002/03).

\section{Mælingar}

Alls var 326 börnum boðin pátttaka og af peim tóku 267 (82\%) pátt í einni eða fleiri mælingum, 148 stúlkur og 119 drengir. Fastandi blóðprufa var tekin á hefðbundinn hátt og D-vítamín var mælt hjá 159 (60\%) pátttakanda, 85 stúlkum og 74 drengjum. Blóðprufur voru rannsakaðar á rannsóknarstofu Landspítalans og DiaSorin 25-OH Vitamin D RIAH tækni notuð til að mæla D-vítamín. Hæð var mæld í cm og pyngd í kg á hefðbundinn hátt og líkamspyngdarstuðull (BMI) reiknaður $\left(\mathrm{kg} / \mathrm{m}^{2}\right)$. Skilmerki fyrir yfirvigt og offitu voru samkvæmt skilmerkjum skilgreindum af Cole og félögum. ${ }^{15}$ Blóðprýstingur var mældur á staðlaðan hátt í vinstri handlegg og meðaltal priggja mælinga notað við úrvinnslu.

\section{Tölfræð $i$}

Við úrvinnslu gagna var IBM, SPSS Statistics útgáfa 2 notað. Lýsandi tölfræði er sýnd sem meðalgildi ásamt staðalfráviki með 95\% öryggisbili. Tölfræðileg marktækni var miðuð við p-gildi $\leq 0,05$. Við samanburð hópa var t-próf og parað t-próf notað til að meta mun á meðalgildum. Við mat á tengslum milli breyta var Pearson's fylgni notuð.

\section{Niðurstöður:}

D-vítamín var mælt hjá 159 börnum. Ekki reyndist vera marktækur munur á milli kynja, stelpur (n:85 = 44,2 nmól/L), strákar (n:74

Tafla II. Meðalgildi áhættupátta hjarta og æðasjúkdóma meðal barna með eðlileg gildi D-vítamíns og barna með D vítamínskort/vöntun

\begin{tabular}{|c|c|c|c|c|c|c|}
\hline \multicolumn{2}{|l|}{ Eðlilegt D-vítamín } & \multicolumn{2}{|c|}{ D-vítamínskortur /vöntun } & \multirow[b]{2}{*}{$\begin{array}{c}\text { Međalgildi } \\
\text { (stađalfrávik) }\end{array}$} & \multirow[b]{2}{*}{ P-gildi } & \multirow[b]{2}{*}{$95 \% \mathrm{Cl}$} \\
\hline Breytur & $\mathbf{N}(\%)$ & $\begin{array}{c}\text { Meðalgildi } \\
\text { (staðalfrávik) }\end{array}$ & $\mathrm{N}(\%)$ & & & \\
\hline Líkamspyngdarstuðull (kg/m²) & $54(34)$ & $15,8(1,5)$ & $105(66)$ & $16,4(2,1)$ & 0,052 & $-0,006$ to 1,261 \\
\hline Systólískur BP (mmHg) & $49(32)$ & $94(6)$ & $104(68)$ & $95(7)$ & 0,504 & $-1,44$ to 2,91 \\
\hline Díastólískur BP (mmHg) & $49(32)$ & $56(4)$ & $104(68)$ & $56(5)$ & 0,335 & $-2,4$ to 0,81 \\
\hline Kólesteról (mmól/L) & $54(35)$ & $4,5(0,6)$ & $102(65)$ & $4,3(0,7)$ & 0,169 & $-0,37$ to 0,07 \\
\hline HDL (mmól/L) & $54(35)$ & $1,6(0,3)$ & $102(65)$ & $1,5(0,3)$ & 0,044 & $-0,195$ to $-0,002$ \\
\hline LDL (mmól/L) & $30(35)$ & $2,6(0,6)$ & $56(65)$ & $2,5(0,6)$ & 0,184 & $-0,443-0,087$ \\
\hline Príglýseríð (mmól/L) & $54(35)$ & $0,6(0,2)$ & $102(65)$ & $0,6(0,2)$ & 0,867 & $-0,08$ to 0,07 \\
\hline Blóðsykur (mmól/L) & $52(36)$ & $4,6(0,4)$ & $94(64)$ & $4,6(0,3)$ & 0,908 & $-0,101$ to 0,114 \\
\hline HbA1c (mmól/L) & $54(34)$ & $5,3(0,3)$ & $103(66)$ & $5,5(0,2)$ & 0,015 & 0,02 to 0,19 \\
\hline Insúlín (mU/L) & $54(35)$ & $3,4(2,2)$ & $102(65)$ & $4,4(2,3)$ & 0,014 & 0,19 to 1,69 \\
\hline
\end{tabular}



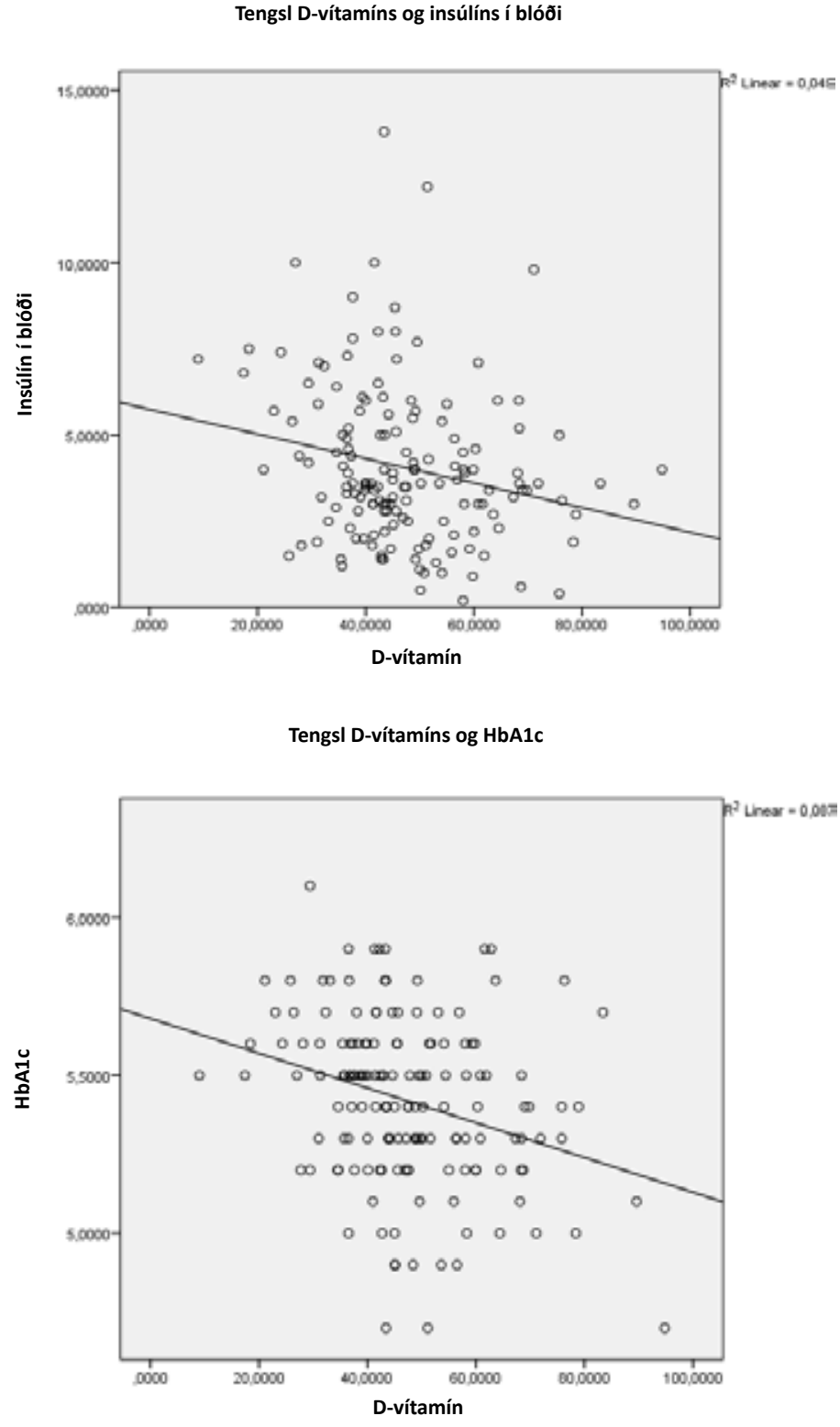

Mynd 1. Tengsl milli D-vítamíns og HbA1c og insúlíns í blóði.

= 46,9 nmól/L), p-gildi 0,52 milli hópa. Af peim voru 35 (22\%) með gildi undir 37,5 nmól/L, 70 (44\%) voru með gildi á milli 37,5 og 50 nmól/L og 55 (34\%) börn höfðu D-vítamíngildi yfir 50 nmól/L. Sex börn voru með D-vítamíngildi undir 25 nmól/L. Tafla I sýnir meðalgildi ýmissa áhættupátta hjarta- og æðasjúkdóma miðað við pessa skiptingu D-vítamíns, sem er algeng skipting pegar verið er að skoða D-vítamín hjá börnum. Tafla II sýnir meðalgildi ýmissa áhættupátta hjarta- og æðasjúkdóma meðal barna sem eru með eðlileg gildi D-vítamíns (yfir 50 nmól/L) samanborið við pau börn sem voru með of lágt gildi (undir 50 nmól/L). Börn með Dvítamínskort hafa tilhneigingu til að hafa hærri líkamspyngdarstuðul (BMI) ( $p=0,052)$, lægra HDL $(p=0,044)$ og hærra HbA1C $(p=0,015)$ og serum insúlín $(p=0,014)$ samanborið við börn með eðlileg D-vítamíngildi, p.e. yfir 50 nmól/L.
Fylgni D-vítamínstyrks og áhættupátta hjarta- og æðasjúkdóma er sýnd í Töflu III. Af pessum áhættupáttum eru insúlín og HbA1C tölfræðilega marktækt tengd lágu D-vítamíngildi en líkamspyngdarstuðull náði ekki tölfræðilegri marktækni ( $\mathrm{p}=0,07)$. Pegar könnuð voru hlutfylgnistengsl áhættupáttanna við D-vítamín, óháð líkamspyngdarstuðli, kom í ljós að insúlín og HbA1C voru enn tölfræðilega marktækt tengd lágu D-vítamíngildi.

Mynd 1 sýnir samband D-vítamíns og styrks insúlíns og HbA1C ásamt viðkomandi $\mathrm{R}^{2}$ gildi, par sem fylgni er marktæk á milli vaxandi styrks D-vítamíns og lækkandi styrks insúlíns í sermi $\left(R^{2}=0,049\right)$.

\section{Umræða}

Pessi rannsókn sýndi að börn sem voru með D-vítamín lægra en 50 nmól/L höfðu marktækt lægra HDL en hærra HbA1c og insúlín samanborið við börn sem höfðu D-vítamín hærra en 50 nmól/L. Í íslenskri rannsókn sem notaði sama gagnagrunn og okkar rannsókn var sýnt fram á að of pung börn höfðu marktækt hærra fastandi insúlín en lægra HDL..$^{14}$ Petta hefur hins vegar aldrei áður verið tengt við D-vítamínstöðu í pessum hópi á Íslandi. Marktæk fylgni var á milli lágs D-vítamíns og hárra gilda insúlíns í blóði $(\mathrm{p}=0,014)$ og hárra gilda HbA1c $(\mathrm{p}=0,015)$ og hélst sú fylgni pegar búið var að leiðrétta fyrir líkamspyngdarstuðli. Рað er vel pekkt að of feit börn og fullorðnir eru líklegri til að hafa lágt D-vítamín. ${ }^{16}$

Í okkar rannsókn voru 14\% barnanna of pung eða of feit, en $66 \%$ með of lágt D-vítamín. D-vítamín hafði neikvæða fylgni við BMI en pað náði ekki marktækni $(\mathrm{p}=0,052)$. Fáar rannsóknir hafa litið á pessa pætti hjá börnum. Í rannsókn í péttbýli hjá skólabörnum á aldrinum 9-14 ára í Somerville, Massachusetts, var skoðað samband milli D-vítamíns, BMI, LDL, HDL, heildarkólesteróls, príglýseríða og CRP. Eingöngu kom fram marktæk fylgni við CRP en ekki HDL eða BMI. ${ }^{17}$ Pað er pvert á pað sem aðrar rannsóknir hafa sýnt um neikvætt samband á milli D-vítamíns og BMI, ${ }^{18,19}$ sem er talið vera vegna aukinnar bindingar D-vítamíns í fituvef. ${ }^{16}$ Kelishadi og fleiri könnuðu tengsl milli D-vítamínskorts og áhættupátta hjartasjúkdóma hjá of feitum börnum og unglingum með pví að gefa peim stóra skammta af D-vítamíni á 12 vikna tímabili og fann út að gjöf D-vítamíns dró úr insúlínviðnámi og lækkaði prí-

Tafla III. Tengs/ D-vítamíns við áhættupætti hjarta- og æðasjúkdóma

\begin{tabular}{lccc}
\hline \multicolumn{1}{c}{ Breytur } & $\begin{array}{c}\text { N (fjöldi } \\
\text { tilfella) }\end{array}$ & $\begin{array}{c}\text { Pearsons } \\
\text { fylgni } \mathbf{r}\end{array}$ & p-gildi \\
\hline BMl $\left(\mathrm{kg} / \mathrm{m}^{2}\right)$ & 159 & $-0,14$ & 0,070 \\
\hline Systólískur BP (mmHg) & 159 & 0,01 & 0,860 \\
\hline Díastólískur BP (mmHg) & 159 & 0,14 & 0,095 \\
\hline Kólesteról (mmól/L) & 159 & 0,08 & 0,301 \\
\hline HDL (mmól/L) & 159 & 0,05 & 0,509 \\
\hline LDL (mmól/L) & 159 & 0,105 & 0,334 \\
\hline Príglýseríð (mmól/L) & 159 & $-0,03$ & 0,744 \\
\hline Insúlín (mmól/L) & 156 & $-0,22$ & 0,005 \\
\hline Blóðsykur (mmól/L) & 146 & 0,00 & 0,966 \\
\hline HbA1C (mmól/L) & 157 & $-0,29$ & $<0,001$ \\
\hline
\end{tabular}


glýseríð. ${ }^{20}$ Rannsóknin var hins vegar eingöngu gerð á of feitum börnum en í okkar rannsókn voru einungis 14\% yfir kjörpyngd. ${ }^{14}$

D-vítamín myndast í húðinni fyrir áhrif sólarljóssins, en sú myndun er hins vegar mjög háð árstíðum. Sýnt hefur verið fram á í íslenskri rannsókn að frá nóvember fram í mars fer fram mjög takmörkuð D-vítamínmyndun í húð og purfa einstaklingar sem ekki taka inn D-vítamín reglulega að treysta á D-vítamín sem geymist í fituforða frá pví sumarið áður eða á inntöku á D-vítamíni. ${ }^{21}$ Íslensk rannsókn sem notaðist við gögn úr sama gagnagrunni og okkar sýndi fram á að gildi D-vítamíns fór lækkandi frá september fram í nóvember, einnig í peim börnum sem tóku inn lýsi. Sú rannsókn pótti sýna fram á mikilvægi pess að börn væru úti á sumrin og snemma hausts og væru útsett fyrir sólargeislum til að byggja upp nægilegan D-vítamínforða fyrir veturinn..$^{22}$ Í landskönnun á mataræði 6 ára barna frá 2011-2012 kom fram að einungis fjórðungur barnanna fékk ráðlagðan dagskammt eða meira af D-vítamíni (sá fjórðungur barna sem tók lýsi) og var D- vítamínneysla fjórðungs barna undir lágmarkspörf $(2,5 \mu \mathrm{g} / \mathrm{dag}) .^{23}$

Раð er engin alpjóðleg samstaða um hvað sé kjörgildi á Dvítamíni. Embætti landlæknis miðar kjörgildi við >50 nmól/L og skort við <30 nmól/L. Athyglisvert er að einungis priðjungur barnanna voru yfir peim gildum sem Embætti landlæknis setur sem viðmiðunargildi D-vítamíns. Alpjóðlega beinpynningarstofnunin (International Osteoporosis Foundation) mælir hins vegar með að kjörgildi miðist við 75 nmól/L eða hærra og fleiri hafa ályktað að kjörgildi sé ekki náð fyrr en við 70-100 nmól/L. ${ }^{24}$ Algengt er pó að miða kjörgildi við 50 nmól/L, vöntun við 37,5 - 50,0 nmól/L og skort minna en 37,5nmól/L hjá börnum og pví var farið eftir peirri skiptingu í okkar rannsókn. ${ }^{25}$ Aðrir draga línuna milli vöntunar og skorts við 25 nmól/L, frekar en 37,5 nmól/L ${ }^{26}$ Bandarísku barnalæknasamtökin (American Academy of Pediatrics) uppfærðu leiðbeiningar sínar árið 2008 og mæla með D-vítamíni yfir 50 nmól/L til að koma í veg fyrir beinkröm, en treystu sér ekki til að mæla með gildum til að hámarka beinheilsu eða minnka líkur á öðrum sjúkdómum sem gætu tengst D-vítamíni. ${ }^{25}$
Gögn frá bandarískri rannsókn á næringu og heilsu, NHANES 2001-2006, varðandi börn og unglinga sýndu að lágt D-vítamín var tengt auknu mittismáli ásamt hærri slagbilsprýstingi og insúlínviðnámi. Pau sýndu jafnframt lægra HDL kólesteról hjá peim sem voru með lægst D-vítamín. ${ }^{27}$. Önnur rannsókn frá Bandaríkjunum komst að pví að börn með lágt D-vítamín höfðu hærri blóðsykur, insúlín og insúlínviðnám eftir að leiðrétt hafði verið fyrir kynproska og líkamspyngdarstuðli. Rannsóknin var hins vegar á börnum með svefnvandamál, en ekki heilbrigðum skólabörnum. ${ }^{28}$

Rétt er að benda á nokkrar takmarkanir varðandi ályktunarhæfni pessara niðurstaðna. Í fyrsta lagi er um nokkuð fámennan rannsóknarhóp að ræða sem veldur pví að í sumum tilvikum að minnsta kosti verður að túlka niðurstöður varfærnislega. Í öðru lagi pá var í rannsókninni stuðst við líkampyngdarstuðul (L) en ekki beinar fitumælingar og pað getur haft áhrif á möguleika okkar til að álykta, svo sem um samband BMI við fitumagn.

\section{Ályktanir:}

D-vítamínskortur hefur verið tengdur við próun hjarta- og æðasjúkdóma. Mikilvægt er að kanna samband pekktra áhættupátta hjarta- og æðasjúkdóma og D-vítamíns, sérstaklega hjá börnum og ungu fólki. Рað er mögulegt að D-vítamínskortur auki áhættu hjartasjúkdóma snemma í lífinu gegnum aukið insúlínviðnám og breytta blóðsykurstjórnun. Pótt ekki hafi verið sýnt fram á orsakasamhengi milli D-vítamíns og hjartasjúkdóma pá telja höfundar að niðurstöður rannsóknarinnar styðji mikilvægi pess að farið sé eftir leiðbeiningum landlæknis um D-vítamíngjöf. Mikið vantar upp á að 7 ára börn á Íslandi uppfylli pau skilyrði par sem 2/3 barnanna voru undir peim kjörgildum sem Embætti landlæknis ráðleggur.

Pakkir: Rannsóknin var styrkt af Vísindasjóði Félags íslenskra heimilislækna og Rannís, Rannsóknamiðstöð Íslands. 


\section{Heimildir}

1. DeLuca HF. Overview of general physiologic feature and functions of vitamin D. American Journal of Clinical Nutrition. 2004; 80:1689S-96S.

2. Xiang W, Kong J, Chen SC, Cao LP, Qiao GL, Zheng W, et al. Cardiac hypertrophy in vitamin $\mathrm{D}$ receptor knockout mice: role of the systemic and cardiac renin-angiotensin systems. Am J Physiol-Endoc M. 2005; 288:E125-E32.

3. Pilz S, Tomaschitz A, Ritz E, Pieber TR. Vitamin D status and arterial hypertension: a systematic review. Nat Rev Cardiol. 2009; 6:621-30.

4. Martins D, Wolf M, Pan D, Zadshir A, Tareen N, Thadhan $\mathrm{R}$, et al. Prevalence of cardiovascular risk factors and the serum levels of 25-hydroxyvitamin D in the United States - Data from the Third National Health and Nutrition Examination Survey. Arch Intern Med. 2007: 167:1159-65.

5. Nemerovski CW, Dorsch MP, Simpson RU, Bone HG Aaronson KD, Bleske BE. Vitamin D and Cardiovascular Disease. Pharmacotherapy. 2009; 29:691-708.

6. Parker J, Hashmi O, Dutton D, Mavrodaris A, Stranges S, Kandala NB, et al. Levels of vitamin D and cardiometabolic disorders: Systematic review and meta-analysis. Maturitas. 2010; 65:225-36.

7. Giovannucci E, Liu Y, Hollis BW, Rimm EB. 25-hydroxyvitamin $D$ and risk of myocardial infarction in men - A prospective study. Arch Intern Med. 2008; 168:1174-80.

8. Reis JP, von Muhlen D, Miller ER, Michos ED, Appel LJ. Vitamin D Status and Cardiometabolic Risk Factors in the United States Adolescent Population. Pediatrics. 2009; 124:E371-E9.

9. Chiu KC, Chu A, Go VLW, Saad MF. Hypovitaminosis D is associated with insulin resistance and beta cell dysfunction. Am J Clin Nutr. 2004; 79:820-5.

10. Krause $\mathrm{R}$, Buhring $\mathrm{M}$, Hopfenmuller $\mathrm{W}$, Holick MF Sharma AM. Ultraviolet B and blood pressure. Lancet. 1998; 352:709-10.
11. Rostand SG, Drueke TB. Parathyroid hormone, vitamin D, and cardiovascular disease in chronic renal failure. Kidney Int. 1999; 56:383-92.

12. Lee JH, O'Keefe JH, Bell D, Hensrud DD, Holick MF. Vitamin D Deficiency An Important, Common, and Easily Treatable Cardiovascular Risk Factor? J Am Coll Cardiol. 2008; 52:1949-56.

13. Anderson JL, May HT, Horne BD, Bair TL, Hall NL, Carlquist JF, et al. Relation of vitamin D deficiency to cardiovascular risk factors, disease status, and inciden events in a general healthcare population. The American journal of cardiology. 2010; 106:963-8.

14. Hrafnkelsson $\mathrm{H}$, Magnusson KT, Sigurdsson EL Johannsson E. Association of BMI and fasting insulin with cardiovascular disease risk factors in seven-year-old Icelandic children. Scand J Prim Health. 2009; 27:186-91.

15. Cole TJ, Bellizzi MC, Flegal KM, Dietz WH. Establishing a standard definition for child overweight and obesity worldwide: international survey. BMJ. 2000; 320:1240-3.

16. Liel Y, Ulmer E, Shary J, Hollis BW, Bell NH. Low Circulating Vitamin-D in Obesity. Calcified Tissue Int 1988; 43:199-201.

17. Sacheck J, Goodman E, Chui K, Chomitz V, Must A, Economos C. Vitamin D Deficiency, Adiposity, and Cardiometabolic Risk in Urban Schoolchildren. J PediatrUs. 2011; 159:945-50.

18. Alemzadeh R, Kichler J, Babar G, Calhoun M. Hypovitaminosis D in obese children and adolescents: relationship with adiposity, insulin sensitivity, ethnicity, and season. Metabolism. 2008; 57:183-91.

19. Hollis BW. Assessment of vitamin D nutritional and hormonal status: What to measure and how to do it Calcified Tissue Int. 1996; 58:4-5.
20. Kelishadi $R$, Salek $S$, Salek $M$, Hashemipour $M$ Movahedian M. Effects of vitamin D supplementation on insulin resistance and cardiometabolic risk factors in children with metabolic syndrome: a triple-masked controlled trial. J Pediatr (Rio J). 2014; 90:28-34

21. Gunnarsson Ö, Indriðason ÓS, Franzson L, Halldórsdóttir E, Sigurðsson G. D-vítamínbúskapur fullorðinna Íslendinga. Læknablaðið 2004;90(1):29-36.

22. Bjarnadottir A, Kristjansdottir AG, Hrafnkelsson $\mathrm{H}_{\text {, }}$ Johannsson E, Magnusson K, Thorsdottir I. Insufficien autumn vitamin $\mathrm{D}$ intake and low vitamin $\mathrm{D}$ status in 7-year-old Icelandic children. Public Health Nutrition 18(2), 208-217

23. Gunnarsdóttir I, Helgadóttir H, Pórisdóttir B, Pórsdóttir I. Landskönnun á mataræði sex ára barna 2011-2012 Læknablaðið 2013; 99(1): 17-23.

24. Zittermann A. Vitamin D and disease prevention with special reference to cardiovascular disease. Prog Biophys Mol Bio. 2006; 92:39-48.

25. Misra M, Pacaud D, Petryk A, Collett-Solberg PF, Kappy M, So LWPE. Vitamin D deficiency in children and its management: Review of current knowledge and recommendations. Pediatrics. 2008; 122:398-417.

26. Pedersen JI. Vitamin D requirement and setting recommendation levels - current Nordic view. Nutr Rev. 2008; 66:S165-S9.

27. Ganji V, Zhang X, Shaikh N, Tangpricha V. Serum 25-hydroxyvitamin $\mathrm{D}$ concentrations are associated with prevalence of metabolic syndrome and various cardiometabolic risk factors in US children and adolescents based on assay-adjusted serum 25-hydroxyvitamin D data from NHANES 2001-2006. Am J Clin Nutr. 2011; 94:225-33.

28. Kelly A, Brooks LJ, Dougherty S, Carlow DC, Zemel BS. A cross-sectional study of vitamin $\mathrm{D}$ and insulin resistance in children. Arch Dis Child. 2011; 96:447-52.

\section{ENGLISH SUMMARY}

\section{The relationship between serum vitamin D levels and cardiovascular risk factors among Icelandic children}

Pórunn Hannesdóttir ${ }^{1,2}$, Hannes Hrafnkelsson ${ }^{1,3}$ Erlingur Jóhannsson4,5, Emil L. Sigurðsson ${ }^{1,2}$

Objective: To determine the relationship between serum vitamin $D$ levels and known cardiometabolic risk factors among healthy Icelandic children as well as study these connections independent of body mass index (BMI).

Methods: We assessed the relationship between serum 25-hydroxyvitamin $\mathrm{D}$, adiposity measured as $\mathrm{BMI}$ and 7 cardiometabolic risk factors (high blood pressure, total cholesterol, high-density lipoprotein cholesterol, low-density lipoprotein cholesterol, triglycerides, blood glucose and serum insulin). Subjects were 7-year old school children in six randomly selected elementary schools in Reykjavik, Iceland, in the autumn of 2006.

Results: Vitamin D was measured amongst 159 children. 35 (22\%) were lower than $37,5 \mathrm{nmol} / \mathrm{L}, 70$ (44\%) between $37,5-50,0 \mathrm{nmol} / \mathrm{L}$ and 55 (34\%) over $50 \mathrm{nmol} / \mathrm{L}$. Deficiency was defined as lower than $37,5 \mathrm{nmol} / \mathrm{L}$. No difference was between girls or boys, girls ( $\mathrm{n}: 85=44,2 \mathrm{nmol} / \mathrm{L}$ ), boys ( $n: 74=46,9 \mathrm{nmol} / \mathrm{L}),(p=0,052)$. Deficient children had higher BMI $(p=0.052)$, lower HDL $(p=0.044)$ and higher HbA1c $(p=0.015)$, and insulin $(p=0.014)$ than those who had vitamin D higher than $50 \mathrm{nmol} / \mathrm{L}$. Significant correlation was between low levels of vitamin $D$ and high levels of serum insulin $(p=0,014)$ and high levels of HbA1c $(p=0,015)$, independent of BMI.

Conclusion: Vitamin D deficiency has been associated with the development of cardiovascular disease. It is important to explore the connection between known risk factors and vitamin $D$ and treat those who are deficient of it, especially children and young adults. It is possible that vitamin $\mathrm{D}$ deficiency has an effect on cardiovascular risk early in life through insulin resistance and altered blood sugar control. It is important to follow guidelines for giving vitamin $D$ to children, as the result showed that $2 / 3$ of the children were under $50 \mathrm{nmol} / \mathrm{L}$.

${ }^{1}$ University of Iceland, Faculty of General Practice, ${ }^{2}$ Solvangur Health care center, ${ }^{3}$ Seltjarnarnes Health care center, ${ }^{4}$ University of Iceland Faculty of sports and medicine, ${ }^{5}$ Department of Sport and Physical Activity, Bergen University College, Bergen, Norway

Key words: Vitamin D, cardiovascular risk factors, insulin

Correspondence: Emil L. Sigurdsson emilsig@hi.is 